\title{
THE IMPORTANCE OF LIFESTYLE MODIFICATIONS FOR THE MANAGEMENT OF COVID-19
}

\author{
A IMPORTÂNCIA DAS MODIFICAÇÕES DE ESTILO DE VIDA PARA A GESTÃO DA \\ COVID-19
}

\section{LA IMPORTANCIA DE LAS MODIFICACIONES DEL ESTILO DE VIDA PARA EL TRATAMIENTO DE LA COVID-19}

Months after the coronavirus disease (COVID-19) outbreak in 2019, which has spread quickly as a pandemic in different parts of the world, affecting all sectors in state agencies and non-governmental organizations (NGOs), while the violation of recommendations for safety and self-care has grown into the most recent global crisis. As the given disease has caused vast closures and disruptions in education, politics, economics, etc., it has led to massive death tolls in the history of humankind. To avoid the rising prevalence rate of this virus, all individuals have to make some changes in their lifestyles, based on new scientific findings, even if these attitudes, ways of life, values, or world views are so far from what are recognized for centuries and managed in accordance with social world trends.

With regard to the conflict between general knowledge and scientific knowledge, it is indispensable to accept scientific findings and to abstain from some habits in social life. To this end, by giving value to scientific knowledge and findings worldwide towards maintaining health and observing its basic principles, it is necessary to ignore many of behavioral habits and characteristics running for thousands of years in daily lives. Under the heading of general knowledge, it contains a part of individuals' reservoirs of knowledge. However, it takes a long time to pave the grounds to welcome these modifications in lifestyles. If a conflict arises in the social world between general knowledge and scientific knowledge, members of the social world typically quit one to win another, here for the benefit of scientific knowledge, to deal with inconsistencies. In this sense, scientific efforts are made in all societies, firstly, to foster and increase awareness, and secondly, to operationalize knowledge, and in the meantime, to enrich

1 Industrial University of Tyumen (IUT), Tyumen - Russia. Associate Professor of the Department of Natural Sciences and Humanities. Researching in the field of the English Language Teaching: interdisciplinary studies in language, language teaching, Teaching and Education in general and other related studies of language. Doctorate in Pedagogics, Teaching Methodology. ORCID: https://orcid.org/0000-0003-0565-8533. E-mail: aigoul@rambler.ru 
general knowledge. Therefore, it is of utmost importance to realize that those having general knowledge are endowed with deep understanding of sociocultural issues, can better recognize social world problems and harms, and even strive to find solutions. Accordingly, putting their guidance into practice, which is to abandon some habits and behavioral characteristics, in order to health return to normality. It is noteworthy that each nation has its own certain culture, customs, and rituals; so, family gatherings, religious ceremonies, public holidays and national celebrations are among the cases demanding much more consideration in this respect.

\section{How to reference this article}

IBATOVA, A. Z. The importance of lifestyle modifications for the management of COVID19. Rev. EntreLínguas, Araraquara, v. 7, n. esp. 1, p. 01-02, fev. 2021. e-ISSN: 2447-3529. DOI: https://doi.org/10.29051/el.v7iEsp1.14852

Submitted: $28 / 10 / 2020$

Required revisions: $19 / 12 / 2020$

Approved: 13/01/2021

Published: 28/02/2021 